\title{
POTAMON GALYANIAE N. SP., A NEW FRESHWATER CRAB FROM THAILAND (DECAPODA, BRACHYURA, POTAMIDAE)
}

\author{
BY \\ PHAIBUL NAIYANETR \\ Department of Biology, Faculty of Science, Chulalongkorn University, Bangkok, Thailand
}

\section{ABSTRACT}

A new species of freshwater crab, Potamon galyaniae, is described from Thailand. The species is close to Potamon boonyaratae (Naiyanetr, 1987); the differences between the two are discussed.

\section{RÉSUMÉ}

Une nouvelle espèce de crabe d'eau douce, Potamon galyaniae, est décrite de Thaïlande. L'espèce est proche de Potamon boonyaratae (Naiyanetr, 1987); les différences entre les deux espèces sont discutées.

\section{INTRODUCTION}

In May 1999, Mr. Mongkol Wongkalasin, Wildlife illustrator of a guide to the birds of Thailand, during a trip undertaken to the region of Tha Chalab, Amphoe Si Sawat, Kanchanaburi Province, western Thailand, collected 3 living specimens of a new species of freshwater crab of the genus Potamon Savigny, 1816, belonging to the family Potamidae Ortmann, 1896. The specimens were found along the banks of the stream Ban Dong Lek, Tha Chalab, Amphoe Si Sawat, Kanchanaburi Province, western Thailand. Two living specimens of the same species were collected from the same place in August 1999. The description of the new species is provided in this paper. The holotype and a female paratype of the new species are deposited in the collection of National Museum of Natural History (RMNH), Leiden, the Netherlands and paratypes are deposited in the collection of Chulalongkorn University, Museum of Zoology, Bangkok, Thailand (CUMZ), in the Natur-Museum Senckenberg, Frankfurt am Main, Germany (SMF), and in the Zoological Reference Collection (ZRC) of the Raffles Museum, National University of Singapore.

The abbreviations $\mathrm{cl}$. and $\mathrm{cb}$. are used for carapace length and carapace width, respectively. 


\section{Potamon galyaniae new species (text-fig. 1, pl. 1)}

Material examined. - Ban Dong Lek Stream, Tha Chalab, Amphoe Si Sawat, Kanchanaburi Province, W. Thailand, in a burrow along the banks of a stream, 22 May 1999, leg. M. Wongkalasin, 1 male holotype (RMNH D 48631), 1 female paratype and 1 male paratype (CUMZ); same locality, 12 August 1999, leg. M. Wongkalasin, 1 male and 1 female paratype; 1 male paratype (ZRC), Kanchanaburi Province, 1999, leg. Thanakham.

A

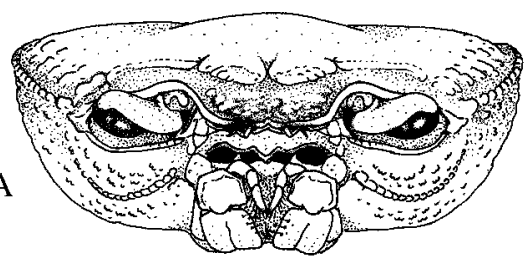

$\mathrm{B}$

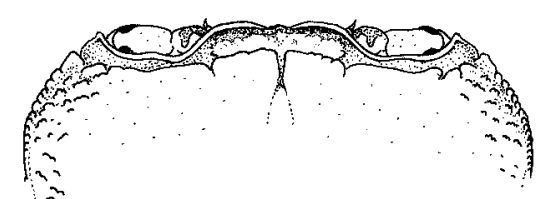

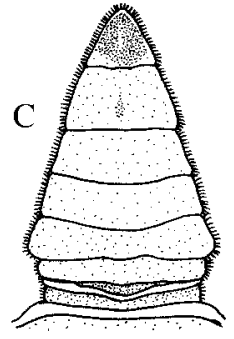

$1 \mathrm{~cm}$

\section{$1 \mathrm{~cm}$}

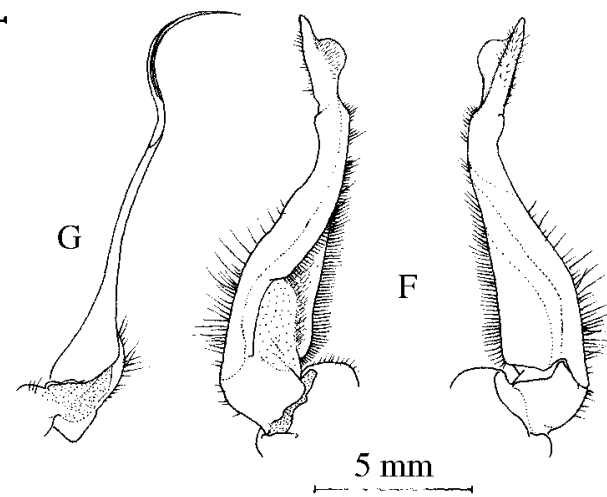

E
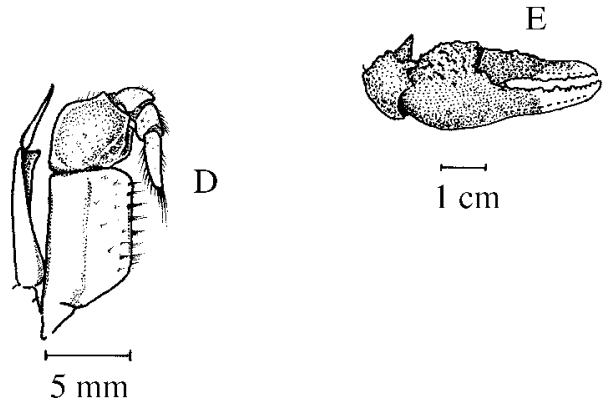

Fig. 1. Potamon galyaniae new species, male. A, thorax in frontal view; B, carapace in dorsal view; C, abdomen; D, third maxilliped; E, chela; F, first gonopod; G, second gonopod. 


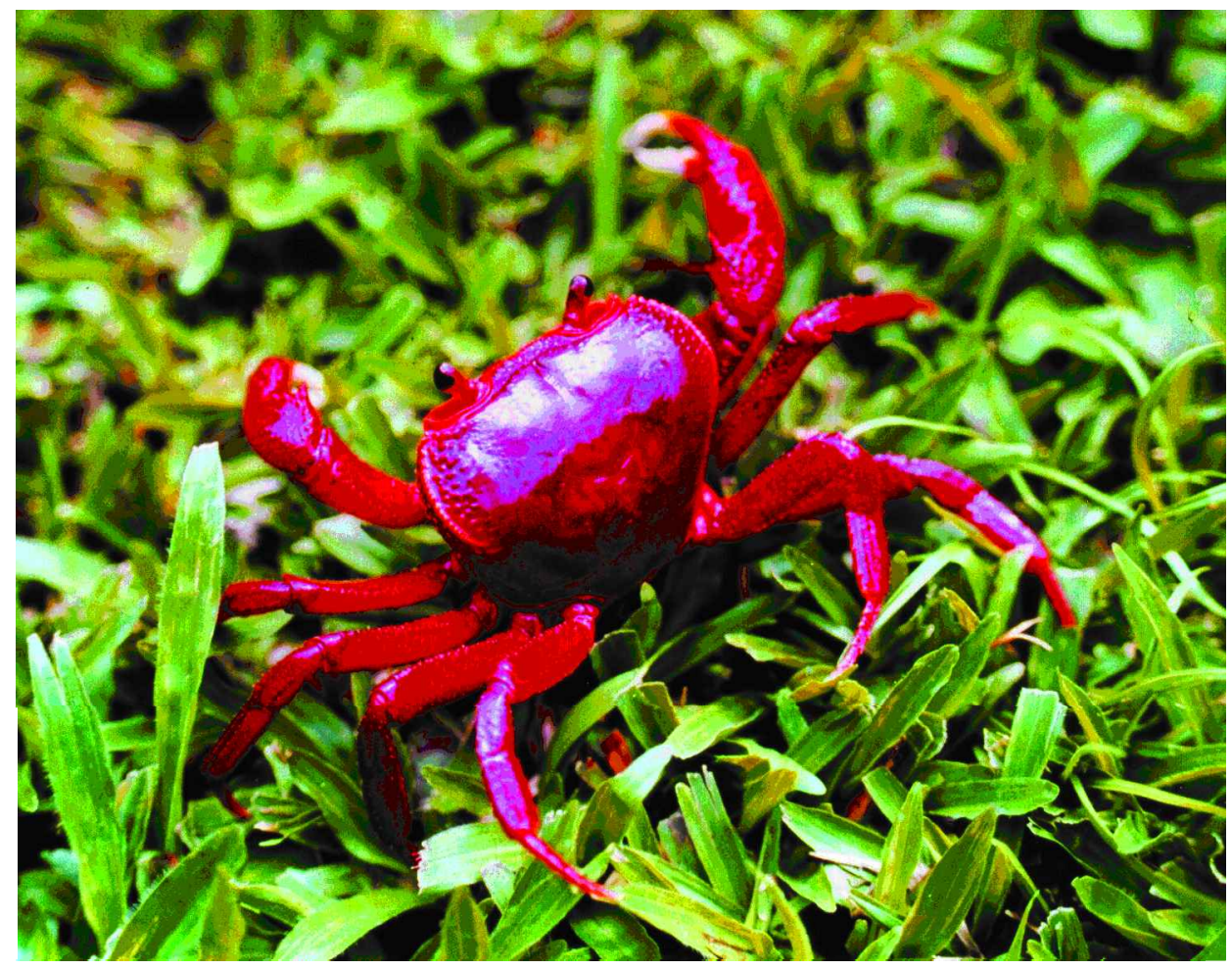

P1. 1. Potamon galyaniae new species, animal in natural surroundings.

Measurements. - Holotype male, cl. $35 \mathrm{~mm}$, cb. $46.5 \mathrm{~mm}$; paratypes: 3 males, cl. 30-34 mm, cb. 42.5-44 mm, 2 females, cl. 27.5-34.5 mm, cb. 37-45 mm.

Etymology. - The specific name is given in honour of Her Royal Highness Princess Galyani Vadhana, as a token of respect and recognition for the special occasion of Her teaching at Chulalongkorn University. Her Royal Highness graciously permitted the use of Her name for this remarkably colourful and most interesting species.

The proposed official Thai name for this species is Pu Phraphinang and the proposed English name Crimson Crab. Locally the species is named $\mathrm{Pu} \mathrm{Pa}$ (= terrestrial crab).

Description. - Carapace relatively high, broader than long; dorsal surface strongly convex, glabrous; regions not well defined, cervical groove poorly developed, not reaching postorbital cristae, $\mathrm{H}$-shaped groove distinct. Epigastric cristae not sharp, rugose, separated by distinct groove, confluent with postorbital cristae, slightly anterior of postorbital cristae. Postorbital cristae distinct, sharp, forming distinct overhang, straight except for a small lateral portion which is slightly uneven, smooth except for the extreme lateral portion which is cristate, sharp, and 
more or less confluent with the epibranchial teeth; regions behind epigastric and postorbital cristae smooth. Frontal margin very gently emarginate medially; frontal region narrow, deflexed downward, granular; supraorbital margins weakly sinuous, infraorbital margins straight, both smooth; orbital region relatively narrow; eyes normal; subhepatic and subbranchial regions rugose. External orbital angle triangular, with outer margin subequal to inner margin, a small but distinct cleft separates the angle from the epibranchial tooth; epibranchial tooth small, distinct, low, cristate. Anterolateral margin of carapace weakly serrated, cristate, convex, running inwards posteriorly, not confluent with posterolateral margin; posterolateral margin entire, straight, converging posteriorly; branchial region slightly granular to weakly rugose; metabranchial region weakly striated. Anterior margin of epistome with a median triangle; its posterior margin with a median triangular tooth.

Ischium of third maxilliped broadly rectangular, 1.4 times longer than broad, with well-developed longitudinal median sulcus; merus squarish, about half as long as ischium, with concave outer surface; palp normal; exopod long, exceeding upper edge of ischium but not reaching midpoint of merus, inner margin of distal part produced as a blunt tooth; flagellum of exopod short, but well-developed, subequal to the width of the merus.

Chelipeds unequal, the right one large, outer surfaces of merus, carpus and palm distinctly rugose; fingers with slight gape when closed, longer than palm, with one or more slightly enlarged cutting edge teeth, tips hooked and overlapping, smooth except for two short longitudinal rows of granules on dorsal surface of movable finger, with several longitudinal rows of pits; carpus with robust, obliquely directed subdistal spine on inner margin; merus without subterminal spine.

Ambulatory legs glabrous; second ambulatory leg with dactylus long, 1.3 times as long as propodus, slender, propodus and carpus smooth, merus sparsely rugose; fourth ambulatory leg with dactylus long, 1.3 times as long as propodus, slender, propodus, carpus and merus smooth.

Suture between sternites 2 and 3 complete, distinct, gently convex; suture between sternites 3 and 4 discernible; male abdominal cavity of sternum reaching level of median points of cheliped bases. Male abdomen narrowly triangular; telson longer than sixth somite, lateral margins almost straight, tip rounded, proximal margin straight; somite 6 with medium length about half the width of the proximal margin, straight; lateral margins of somite 3 to 6 almost straight.

Male first pleopod slightly sinuous, slender, inner margin and groove for gonopod 2 (G2) lined with setae; distal segment clearly separate from subdistal segment, relatively short, about 0.4 times length of subdistal segment, conical, straight, distal part of inner margin straight, distal part of outer margin gently tapering, tip rounded, dorsal flap well-developed, broad; subdistal segment slender, sinuous. G2 with distal segment subequal to half of basal segment. 
Colour. - In living specimens, the carapace and walking legs are of a deep red colour. The anterolateral and orbital crests as well as the epistome are orange-red. The chelipeds are deep red except for the distal halves of the fingers, which are white.

Habitat. - Like some other species of Potamon, the present one is a terrestrial animal. It is found in deep burrows in the banks of small, heavily shaded streams in dense forests. The banks of the streams consist of mud and are overgrown by herbs.

Systematic position. - Potamon galyaniae resembles Potamon boonyaratae (Naiyanetr, 1987), from Khao Rakam, Amphoe Muang, Trat Province, eastern Thailand. The latter species differs from the former in several morphological characters. In $P$. boonyaratae the first male gonopod is more distinctly curved outward; the lobe of the ultimate segment is lower than in P. galyaniae; in the second male gonopod, the distal part is not hook-like curved in $P$. galyaniae; the lateral margins of the sixth abdominal somite of $P$. boonyaratae are convex, those of the telson are concave, and differ from those of $P$. galyaniae, where they are almost straight. The colour of the living animal in $P$. boonyaratae is dark and differs from that of $P$. galyaniae, in which it is deep red with the distal parts of the fingers of the chelae white.

\section{ACKNOWLEDGEMENTS}

I would like to express my thanks to Dr. L. B. Holthuis, National Museum of Natural History, Leiden, the Netherlands, for reading and correcting the manuscript and for his suggestions and comments, to Mr. D. C. Yeo, Department of Biological Sciences, National University of Singapore, for his help with the description, to Mr. Priyawut Vatcharanond for preparing the illustrations and to Mr. Mongkol Wongkalasin, Wildlife illustrator, for his great help in collecting the freshwater crabs dicussed here.

\section{REFERENCE}

NG, P. K. L. \& P. NAiYAnetr, 1993. New and recently described freshwater crabs (Crustacea: Decapoda: Brachyura: Potamidae, Gecarcinucidae and Parathelphusidae)from Thailand. Zool. Verhand., Leiden, 284: 1-117, figs. 1-68. 